\title{
Developmental Origins of Adult Disease
}

\author{
Rebecca A. Simmons, M.D. \\ Department of Pediatrics Children's Hospital Philadelphia and University of Pennsylvania School \\ of Medicine, Philadelphia, Pennsylvania 19104
}

\begin{abstract}
Intrauterine growth retardation (IUGR) has been linked to later development of type 2 diabetes in adulthood. Human studies indicate that individuals who were growth retarded at birth have impaired insulin secretion and insulin resistance. Multiple animal models of IUGR demonstrate impaired B-cell function and development. We have developed a model of IUGR in the rat that leads to diabetes in adulthood with the salient features of most forms of type 2 diabetes in the human: progressive defects in insulin secretion and insulin action prior to the onset of overt hyperglycemia. Decreased B-cell proliferation leads to a progressive decline in B-cell mass. Using this model, we have tested the hypothesis that uteroplacental insufficiency disrupts the function of the electron transport chain in the fetal $\beta$-cell and leads to a debilitating cascade of events: increased production of reactive oxygen species, which in turn damage mitochondrial (mt) mtDNA and causes further production of reactive oxygen species (ROS). The net result is progressive loss of $\beta$-cell function and eventual development of type 2 diabetes in the adult. Studies in the IUGR rat also demonstrate that an abnormal intrauterine environment induces epigenetic modifications of key genes regulating $\beta$-cell development; experiments directly link chromatin remodeling with suppression of transcription. Future research will be directed at elucidating the mechanisms underlying epigenetic modifications in offspring.
\end{abstract}

\section{Keywords}

intrauterine growth retardation; type 2 diabetes; fetal origins of adult disease; epigenetics; mitochondria; oxidative stress

\section{Introduction}

The period from conception to birth is a time of rapid growth, cellular replication and differentiation, as well as functional maturation of organ systems. These processes are very sensitive to alterations in the intrauterine milieu. Programming describes the mechanisms whereby a stimulus or insult at a critical period of development has lasting or lifelong effects. This review will discuss the human and animal data supporting the Developmental Origin's of Adult Disease hypothesis and some of the underlying cellular and molecular mechanisms responsible for the observed defects in B-cell function and development.

\footnotetext{
(c) 2009 Elsevier Inc. All rights reserved.

Correspondence, Proofs, and Reprint requests: Rebecca Simmons M.D. University Pennsylvania BRB II/III, Rm 1308421 Curie Blvd Philadelphia, PA 19104 Tele: 215-746-5139 Fax: 215-573-7627 rsimmons@ mail.med.upenn.edu.

Publisher's Disclaimer: This is a PDF file of an unedited manuscript that has been accepted for publication. As a service to our customers we are providing this early version of the manuscript. The manuscript will undergo copyediting, typesetting, and review of the resulting proof before it is published in its final citable form. Please note that during the production process errors may be discovered which could affect the content, and all legal disclaimers that apply to the journal pertain.
} 


\section{Low Birth Weight}

It is becoming increasingly apparent that the in utero environment in which a fetus develops may have long-term effects on subsequent health and survival $(1,2)$. The landmark cohort study of 300,000 men by Ravelli and colleagues showed that exposure to the Dutch famine of 1944-45 during the first one-half of pregnancy resulted in significantly higher obesity rates at age 19 years (3). Subsequent studies of English men demonstrated a relationship between low birth weight and the later development of cardiovascular disease (4) and impaired glucose tolerance (5-8). Other studies of populations in the United States (9-11), Sweden (12), France (13, 14), Norway (15), and Finland (16), have demonstrated a significant correlation between low birth weight and the later development of adult diseases. The associations with low birth weight and increased risk of coronary heart disease, stroke, and type 2 diabetes remain strong, even after adjusting for lifestyle factors (e.g.,smoking, physical activity, occupation, income, dietary habits, childhood socio-economic status) and occur independent of the current level of obesity or exercise (17).

\section{High Birth Weight}

An increased birth weight is associated with an enhanced body mass index (BMI) and an elevated prevalence of adulthood obesity (18). Those individuals who are obese as adults tend to have been heavier at birth and to have had an accelerated gain in body mass through childhood and adolescence. Factors in early childhood may lead to obesity through metabolic programming (discussed below) or establishment of lifestyle behaviors. During infancy, breastfeeding may protect against the development of excess weight during childhood. Most, but not all, epidemiological studies demonstrate this protective effect, which could be mediated by behavioral and/or physiological mechanisms. Confounding cultural factors associated with both the decision to breastfeed and later obesity, however, are possible. Recent data also suggest that rapid weight gain during infancy is associated with obesity later in childhood, perhaps reflecting a combination of genetically determined catch-up growth and postnatal environmental factors (18).

\section{Low Birth Weight and Insulin Secretion}

It remains controversial as to whether the adverse effects of intrauterine growth retardation on glucose homeostasis are mediated through programming of the fetal endocrine pancreas (1). Growth-retarded fetuses and newborns have been reported to have both a reduced population of pancreatic $\beta$-cells (19) or a normal percentage of pancreatic area occupied by B-cells (20). Both of these studies were observational, morphometric analyses were not optimal, and only a small number of fetuses/newborns were examined. It is likely that a significant proportion, but not all growth-retarded fetuses will have reduced B-cell numbers. A more clinically relevant consideration is the impact of fetal growth retardation upon $\beta$-cell function.

Intrauterine growth retarded (IUGR) fetuses have been found to exhibit lower insulin and glucose levels and higher G/I ratio in the third trimester as measured by cordocentesis (21). Two recent studies showed that IUGR infants display decreased pancreatic $\beta$-cell function, but increased insulin sensitivity at birth $(22,23)$. Low birth weight has been associated with reduced insulin response after glucose ingestion in young non-diabetic men, whereas, other studies have found no impact of low birth weight upon insulin secretion $(17,18)$. However, none of these earlier studies adjusted for the corresponding insulin sensitivity, which has a profound impact upon insulin secretion. Therefore, Jensen and colleagues (24) measured insulin secretion and insulin sensitivity in a well-matched Caucasian population of 19-yearold glucose tolerant men with birth-weights of either below the 10th percentile (small for gestational age-SGA) or between the 50th-75th percentile (controls). To eliminate the major 
confounders such as "diabetes genes", none of the participants had a family history of diabetes, hypertension, or ischemic heart disease. There was no difference between the groups with regard to current weight, body mass indes (BMI), body composition, and lipid profile. When controlled for insulin sensitivity, insulin secretion was reduced by $30 \%$. Insulin sensitivity, however, was normal in the SGA subjects. The investigators hypothesized that defects in insulin secretion may precede defects in insulin action and that once SGA individuals accumulate body fat, they will develop insulin resistance (24).

\section{Insulin Secretion in Offspring of Diabetic Mothers}

Several epidemiological studies show that the risk for diabetes is significantly higher in the offspring of mothers who have type 2 diabetes (25-28). It is likely that impaired B-cell function contributes to this increased risk. Islet hypertrophy and B-cell hyperplasia are typical features of fetuses and newborns of diabetic mothers (29). Most studies have focused on altered glucose homeostasis during the newborn period; two clinical investigations done at older ages, however, demonstrate altered insulin secretion $(28,30)$. Thus, both a deficiency and a surfeit of nutrient availability to the fetus during development have profound lasting effects upon $\beta$-cell function.

\section{Genetics versus Environment}

Several epidemiological and metabolic studies of twins and first-degree relatives of patients with type 2 diabetes have demonstrated an important genetic component of diabetes (31-34). The association between low birth weight and risk of type 2 diabetes in some studies could theoretically be explained by a genetically-determined reduced fetal growth rate. In other words, the genotype responsible for type 2 diabetes may itself cause retarded fetal growth in utero. This forms the basis for the fetal insulin hypothesis, which suggests that geneticallydetermined insulin resistance could result in low insulin-mediated fetal growth in utero as well as insulin resistance in childhood and adulthood (35). Insulin is one of the major growth factors in fetal life and monogenic disorders that affect fetal insulin secretion or fetal insulin resistance also affect fetal growth. Mutations in the gene encoding glucokinase have been identified that result in low birth weight and maturity onset diabetes of the young (36, 372).

The recently described type 2 diabetes susceptibility gene Transcription Factor7-like 2 (TCF7L2) confers a risk-allele frequency of approximately $30 \%$ (38). Studies of nondiabetic subjects show that TCF7L2 diabetes-risk genotypes alter insulin secretion (39-41). A large study of 24,053 subjects from six studies demonstrated that TCF7L2 is the first type 2 diabetes gene to be reproducibly associated with altered birth weight. Each maternal copy of the $\mathrm{T}$ allele at re7903146 increased offspring birth weight by 30 grams, and the investigators suggest that the most likely mechanism is through reduced maternal-insulin secretion resulting in maternal hyperglycemia and increased insulin-mediated fetal growth (42).

Recent genetic studies suggest that the increased susceptibility to type 2 diabetes of subjects who are born SGA also results from the combination of both genetic factors and an unfavorable fetal environment. Polymorphisms of Peroxisome Proliferator-Activated Receptor-gamma 2 (PPARg2), a gene involved in the development and in the metabolic function of adipose tissue, have been shown to modulate the susceptibility of subjects who are born SGA to develop insulin resistance later in life $(43,44)$. The polymorphism is only associated with a higher risk of type 2 diabetes if birth weight is reduced $(43,44)$. There is obviously a close relationship between genes and the environment. Not only can maternal gene expression alter the fetal environment, the maternal intrauterine environment also affects fetal gene expression and both influence birth weight. 


\section{What Animal Models Can Tell Us}

Animal models have a normal genetic background upon which environmental effects during gestation or early postnatal life can be tested for their role in inducing diabetes. Ontogeny of ß-cell development in the rodent approximates what has been observed in the human $(45,46)$. The most commonly used animal models for IUGR are caloric or protein restriction, glucocorticoid administration, or induction of uteroplacental insufficiency in the pregnant rodent. In the rat, maternal dietary protein restriction (approximately $40-50 \%$ of normal intake, termed LP) throughout gestation and lactation has been reported to alter insulin secretory capacity and reduce $\beta$-cell mass through a reduction in $\beta$-cell proliferation rate and an increase in apoptosis (47-55). Expression of Pdx-1 (pancreatic duodenal homeobox-1), a homeodomain-containing transcription factor that regulates early development of both endocrine and exocrine pancreas, and later differentiation and function of $\beta$ cells (56), is also reduced in islets from pups of LP mothers (57). In adulthood, rats born from LP mothers still have reductions in B-cell mass and insulin secretion and show glucose intolerance, but usually not overt diabetes $(47,48,55)$. In old age, LP offspring develop fasting hyperglycemia associated with insulin resistance (58-62)

Total caloric restriction during the last week of pregnancy and throughout lactation also reduces $\beta$-cell mass and impairs insulin secretion in the offspring $(63,64)$. When maternal undernutrition is prolonged until weaning and normal nutrition is given to the offspring from weaning onwards, growth retardation and beta-cell mass reduction persists into adulthood (64).

Treatment of pregnant rats with dexamethasone during the last week of gestation retards fetal growth (65). Insulin content of fetal beta-cells is reduced and is associated with a reduction in Pdx-1 (65).

An ovine model of IUGR induced by placental insufficiency (heat-induced) results in a significant reduction in $B$-cell mass in fetuses near term ( 0.9 of gestation) from decreased rates of $\beta$-cell proliferation and neogenesis (66). Plasma insulin concentrations in the IUGR fetuses are lower at baseline and glucose-stimulated insulin secretion is impaired. Similar deficits occur with arginine-stimulated insulin secretion. A deficiency in islet glucose metabolism also occurs in the rate of islet glucose oxidation at maximal stimulatory glucose concentrations. Thus, pancreatic islets from nutritionally-deprived IUGR fetuses caused by chronic placental insufficiency have impaired insulin secretion caused by reduced glucosestimulated glucose oxidation rates, insulin biosynthesis, and insulin content. This impaired glucose stimulated insulin secretion (GSIS) occurs despite an increased fractional rate of insulin release from a greater proportion of releasable insulin as a result of diminished insulin stores (67).

To extend these experimental studies of growth retardation, we developed a model of IUGR in the rat that restricts fetal growth (68-70). Growth-retarded fetal rats have critical features of a metabolic profile characteristic of growth-retarded human fetuses: decreased levels of glucose, insulin, IGF-I, amino acids, and oxygen (68-72). Birth weights of IUGR animals are significantly lower than those of controls until approximately 7 weeks of age, when IUGR rats catch up to controls. Between 7 and 10 weeks of age, the growth of IUGR rats accelerates and surpasses that of controls, and by 26 weeks of age, IUGR rats are obese (69). No significant differences are observed in blood glucose and plasma insulin levels at 1 week of age. Between 7 and 10 weeks of age, however, IUGR rats develop mild fasting hyperglycemia and hyperinsulinemia. IUGR animals are glucose-intolerant and insulinresistant at an early age. First-phase insulin secretion in response to glucose is also impaired early in life in IUGR rats, before the onset of hyperglycemia. There are no significant 
differences in beta-cell mass, islet size, or pancreatic weight between IUGR and control animals at 1 and 7 weeks of age. In 15-week-old IUGR rats, however, the relative beta-cell mass is $50 \%$ that of controls, and by 26 weeks of age, beta-cell mass is less than one-third that of controls. This loss of $\beta$-cell mass is accompanied by a reduction in Pdx-1 expression that is greater than that in $\beta$-cell mass (73). By 6 months of age, IUGR rats develop diabetes with a phenotype remarkably similar to that observed in the human with type 2 diabetes: progressive dysfunction in insulin secretion and insulin action (69). Thus, despite different animal models of IUGR, these studies support the hypothesis that an abnormal intrauterine milieu can induce permanent changes in $\beta$-cell function after birth and lead to type 2 diabetes in adulthood.

\section{Cellular Mechanisms: Mitochondrial dysfunction and oxidative stress}

Uteroplacental insufficiency, caused by such disorders as preeclampsia, maternal smoking and abnormalities of uteroplacental development, is one of the most common causes of fetal growth retardation. The resultant abnormal intrauterine milieu restricts the supply of crucial nutrients to the fetus, thereby limiting fetal growth. Multiple studies have shown that intrauterine growth retardation is associated with increased oxidative stress in the human fetus (73-80). A major consequence of limited nutrient availability is an alteration in the redox state in susceptible fetal tissues leading to oxidative stress. In particular, low levels of oxygen, evident in growth-retarded fetuses, will decrease the activity of complexes of the electron transport chain, which will generate increased levels of reactive oxygen species (ROS). Overproduction of ROS initiates many oxidative reactions that lead to oxidative damage not only in the mitochondria but also in cellular proteins, lipids, and nucleic acids. Increased ROS levels inactivate the iron-sulfur centers of the electron transport chain complexes, and tricarboxylic acid cycle aconitase, resulting in shutdown of mitochondrial energy production.

A key adaptation enabling the fetus to survive in a limited energy environment may be the reprogramming of mitochondrial function. However, these alterations in mitochondrial function can have deleterious effects, especially in cells that have a high-energy requirement, such as the B-cell. The B-cell depends upon the normal production of ATP for nutrient-induced insulin secretion (81-88) and proliferation (89). Thus, an interruption of mitochondrial function can have profound consequences for the $\beta$-cell.

Mitochondrial dysfunction can also lead to increased production of ROS, which causes oxidative stress if the defense mechanisms of the cell are overwhelmed. B-cells are especially vulnerable to ROS because expression of antioxidant enzymes in pancreatic islets is very low (90. 91), and B-cells have a high oxidative energy requirement. Increased ROS impair glucose-stimulated insulin secretion $(92,93)$, decrease gene expression of key $\beta$-cell genes (94-98), and induce cell death (98-103).

We have examined the causal role of mitochondrial dysfunction in the impairment of $\beta$-cell function and development in IUGR offspring (104). Reactive oxygen species production and oxidative stress gradually increase in IUGR islets. ATP production is impaired and continues to deteriorate with age. The activities of complex I and III of the electron transport chain progressively decline in IUGR islets. Mitochondrial DNA point mutations accumulate with age and are associated with decreased mitochondrial DNA content and reduced expression of mitochondria-encoded genes in IUGR islets. Mitochondrial dysfunction results in impaired insulin secretion. These results demonstrate that IUGR induces mitochondrial dysfunction in the fetal beta-cell, leading to increased production of ROS, which in turn damage mitochondrial DNA. A self-reinforcing cycle of progressive deterioration in mitochondrial function leads to a corresponding decline in beta-cell 
function. Finally, a threshold in mitochondrial dysfunction and ROS production is reached, and diabetes ensues (104).

\section{Molecular Mechanisms: Epigenetic Regulation}

An adverse intrauterine milieu impacts the development of the fetus by modifying gene expression in both pluripotential cells and terminally differentiated, poorly replicating cells such as the $\beta$-cell. The long-range effects on the offspring [into adulthood] depend upon the cells undergoing differentiation, proliferation, and/or functional maturation at the time of the disturbance in maternal fuel economy. Permanent alterations to the phenotype of the offspring suggest that fetal growth retardation is associated with stable changes in gene expression.

Epigenetic modifications of the genome provide a mechanism that allows the stable propagation of gene activity states from one generation of cells to the next. Excellent reviews on this topic appear frequently, reflecting the rapid advances of knowledge in the field (105-108). Epigenetic states can be modified by environmental factors, which may contribute to the development of abnormal phenotypes. There are at least two distinct classes of epigenetic information that can be inherited with chromosomes. One class of epigenetic control of gene expression involves changes in chromatin proteins, usually involving modifications of histone tails. The amino termini of histones can be modified by acetylation, methylation, sumoylation, phosphorylation, glycosylation, and ADP ribosylation. The most common modifications involve acetylation and methylation of lysine residues in the amino termini of $\mathrm{H} 3$ and $\mathrm{H} 4$. Increased acetylation induces transcription activation, whereas decreased acetylation usually induces transcription repression. Methylation of histones is associated with both transcription repression and activation.

The second class of epigenetic regulation is DNA methylation, in which a cytosine base is modified by a DNA methyltransferase at the C5 position of cytosine, a reaction that is carried out by various members of a single family of enzymes. Approximately $70 \%$ of $\mathrm{CpG}$ (cytosine-guanine) dinucleotides in human DNA are constitutively methylated, whereas most of the unmethylated CpGs are located in $\mathrm{CpG}$ islands. CpG islands are CG-rich sequences located near coding sequences, and serve as promoters for the associated genes. Approximately half of mammalian genes have $\mathrm{CpG}$ islands. Methylation of $\mathrm{CpG}$ sites is also maintained by DNA methyltransferases. DNA methylation is commonly associated with gene silencing and contributes to X-chromosomal inactivation, genomic imprinting, as well as transcriptional regulation of tissue-specific genes during cellular differentiation (108).

Most $\mathrm{CpG}$ islands remain unmethylated in normal cells, however, under some circumstances such as cancer (109-114) and oxidative stress (see below), they can become methylated de novo. This aberrant methylation is accompanied by local changes in histone modification and chromatin structure, such that the $\mathrm{CpG}$ island and its embedded promoter acquire a repressed conformation that is incompatible with gene transcription. It is not known why particular $\mathrm{CpG}$ islands are susceptible to aberrant methylation. A study by Feltus et al (115) suggests that there is a "sequence signature associated with aberrant methylation". Of major significance to type 2 diabetes is their finding that $P d x-1$ is one of only $15 \mathrm{CpG}$ genes (a total of 1749 genes with $\mathrm{CpG}$ islands were examined) that is susceptible to increased methylation from over-expression of a DNA methyltransferase.

Hypermethylation of specific genes has also been observed in tissues of aging individuals (113). As an age-related disease, type 2 diabetes increases in prevalence in older populations as the metabolic profile of individuals deteriorates with time. DNA methylation errors that accumulate with increasing age could explain this phenomenon, perhaps through induction of oxidative stress. 
Reactive oxygen species can also lead to alterations in DNA methylation, without changing the DNA base sequence (116). Such changes in DNA methylation patterns have been shown to affect the expression of multiple genes (116). Replacement of guanine with the oxygen radical adduct 8-hydroxyguanine profoundly alters methylation of adjacent cytosines (116). Histones, because of their abundant lysine residues, are also very susceptible to oxidative stress (117-119).

\section{Epigenetic regulation of gene expression in fetal growth retardation}

A number of studies have suggested that uteroplacental insufficiency induces epigenetic modifications in the offspring (120-124). Genome-wide DNA hypomethylation has been found in postnatal IUGR liver and is associated with an increase in total $\mathrm{H} 3$ acetylation (120). Acetylation of histone H3 and acetylation of H3 lysine-9 (H3/K9), lysine-14 (H3/ $\mathrm{K} 14)$, and lysine-18 (H3/K18) is increased at the promoters of PPAR-coactivator-1 (PGC-1) and Carnitine palmitoyltransferase 1 (CPTI), respectively, in IUGR liver (122). At day 21 of life, the neonatal pattern of $\mathrm{H} 3$ hyperacetylation persists only in the IUGR males. Whether hyperacetylation at these sites actually causes increased transcription of PGC-1 or CPT1 and how these findings relate to a phenotype in the offspring remains to be determined.

\section{Chromatin Remodeling in the B-cell of IUGR rats}

Studies in the IUGR rat also demonstrate that fetal growth retardation induces epigenetic modifications of key genes regulating $B$-cell development (125). $P d x$-1 is a homeodomaincontaining transcription factor that plays a critical role in the early development of both endocrine and exocrine pancreas, and then in the later differentiation and function of the $\beta$ cell. As early as 24 hours after the onset of growth retardation, $P d x-1$ mRNA levels are reduced by more than $50 \%$ in IUGR fetal rats. Suppression of $P d x-1$ expression persists after birth and progressively declines in the IUGR animal, implicating an epigenetic mechanism.

Chromatin modification mechanisms serve a critical function in affecting the transcriptional status of genes. Our data demonstrate that the open chromatin domain marked by histone $\mathrm{H} 3$ and $\mathrm{H} 4$ acetylation at the proximal promoter of $P d x 1$ is essential for transcription. Robust $P d x 1$ expression in islets from control animals is coincident with the presence of acetylated histones $\mathrm{H} 3$ and $\mathrm{H} 4$ as well as trimethylated H3K4. Loss of these marks results in $P d x 1$ silencing and reversal of IUGR induced epigenetic modifications normalizes $P d x 1$ expression. These data suggest that histone modifications can be stably propagated throughout life.

The first epigenetic mark that is modified in B-cells of IUGR animals is histone acetylation (Figure 1). Islets isolated from IUGR fetuses show a significant decrease in $\mathrm{H} 3$ and $\mathrm{H} 4$ acetylation at the proximal promoter of $P d x 1$. These changes in $\mathrm{H} 3$ and $\mathrm{H} 4$ acetylation are associated with a loss of binding of USF-1 to the proximal promoter of $P d \times 1$. USF-1 is a critical activator of $P d x 1$ transcription and decreased binding markedly decreases $P d x 1$ transcription $(126,127)$. After birth, histone deacetylation progresses and is followed by a marked decrease in $\mathrm{H} 3 \mathrm{~K} 4$ trimethylation and a significant increase in dimethylation of H3K9 in IUGR islets (Figure 1). Progression of these histone modifications parallels the progressive decrease in $P d x 1$ expression as glucose homeostasis deteriorates and oxidative stress increases in IUGR animals. Nevertheless, in the IUGR pup (at 2 weeks of age) these silencing histone modifications alone suppress $P d \times 1$ expression since there is no appreciable methylation in the $\mathrm{CpG}$ island and reversal of histone deacetylation in IUGR islets (in the presence of active $\beta$-cell replication) is sufficient to nearly normalize $P d x 1$ mRNA levels.

The initial mechanism by which IUGR silences $P d x 1$ is by recruitment of co-repressors, including $\mathrm{HDAC} 1$ and $\mathrm{mSin} 3 \mathrm{~A}$, which catalyze histone deacetylation - the first repressive 
mark observed at $P d x 1$ in IUGR islets. Binding of these deacetylases in turn facilitates loss of trimethylation of $\mathrm{H} 3 \mathrm{~K} 4$ further repressing $P d x 1$ expression (Figure 1). Our observation that inhibition of HDAC activity by TSA treatment normalizes H3K4me3 levels at $P d x 1$ in IUGR islets suggests that the association of HDAC1 at $P d x 1$ in IUGR islets likely serves as a platform for the recruitment of a demethylase, which catalyzes demethylation of H3K4.

As described above, DNA methylation of a $\mathrm{CpG}$ island in the promoter is a key mechanism for silencing gene expression. Most $\mathrm{CpG}$ islands remain unmethylated in normal cells, however, under conditions of oxidative stress $(116,128-130), \mathrm{CpG}$ islands can become methylated de novo. This is particularly relevant to type 2 diabetes, as there are now substantial data that show that oxidative stress plays a significant role in the progression of B-cell deterioration (131-135). Further, IUGR induces mitochondrial dysfunction in the Bcell leading to increased production of ROS and oxidative stress (104). It is not known why particular $\mathrm{CpG}$ islands are susceptible to aberrant methylation. A study by Feltus et al (115) suggests that there is a "sequence signature associated with aberrant methylation". Of particular relevance to this study is their finding that $P d x 1$ and a flanking gene, $C d x$-2 (also encoding a homeobox protein), were two of only 15 genes (a total of 1749 genes with CpG islands were examined) that were methylation susceptible under conditions of increased methylation induced by overexpression of DNMT1.

The molecular mechanism responsible for DNA methylation in IUGR islets is likely to involve H3K9 methylation. A number of studies have shown that methylation of H3K9 precedes DNA methylation $(136,137)$. It has also been suggested that DNA methyltransferases may act only on chromatin that is methylated at lysine 9 on histone $\mathrm{H} 3$ (H3K9) (137). Histone methyltransferases bind to the DNA methylases DNMT3A and DNMT3B thereby initiating DNA methylation (136).

These results demonstrate that IUGR induces a self-propagating epigenetic cycle in which the mSin $3 \mathrm{~A} / \mathrm{HDAC}$ complex is first recruited to the $P d x 1$ promoter, histone tails are subjected to deacetylation and $P d x 1$ transcription is repressed. At the neonatal stage, this epigenetic process is reversible and may define an important developmental window for therapeutic approaches. However, as dimethylated H3K9 accumulates, DNMT3A is recruited to the promoter and initiates de novo DNA methylation, which locks in the silenced state in the IUGR adult pancreas resulting in diabetes. Our studies indicate novel mechanisms of epigenetic regulation of gene expression in vivo which link gene silencing in the $\beta$-cell to the development of type 2 diabetes and suggest novel therapeutic agents for the prevention of common diseases with late-onset phenotypes.

How do these events lead to diabetes? Targeted homozygous disruption of $P d x-1$ in mice results in pancreatic agenesis (reviewed in 138), and homozygous mutations yield a similar phenotype in humans (138). Milder reductions in $P d x$-1 protein levels, as occurs in the $P d x$ $+/-$ mice, allow for the development of a normal mass of $\beta$ cells (138), but result in the impairment of several events in glucose-stimulated insulin secretion (138). These results indicate that $P d x-1$ plays a critical role, distinct from its developmental role, in the normal function of $\beta$ cells (138). This may be the reason that humans with heterozygous missense mutations in $P d x-1$ exhibit early and late onset forms of type 2 diabetes (138).

\section{Chromatin Remodeling in Muscle of IUGR rats}

A reduction in glucose transport in muscle has been shown to be a central basis for insulin resistance in the IUGR offspring $(139,140)$. Glucose transport, a rate-limiting step in glucose utilization under normal physiological circumstances, occurs by facilitated diffusion (141). This process is mediated by a family of structurally related membrane-spanning glycoproteins, termed the facilitative glucose transporters (GLUT; Slc2 family of transport 
proteins) (reviewed in 142). Of the isoforms cloned to date, GLUT4 is the major insulinresponsive isoform expressed in insulin-sensitive tissues such as skeletal muscle, adipose tissue and cardiac muscle (142). The promoter region of GLUT4 has been well characterized and disruption of the myocyte enhancer factor 2 (MEF2)-binding site ablates tissue-specific glut4 expression in transgenic mice (142). MyoD on the other hand is responsible for glut 4 expression in vitro during myoblast to myocyte differentiation (143). MyoD binding with that of MEF2 and TR 1 spans the 502- to 420-bp region of the glut4 gene in skeletal muscle. These two proteins synergistically skeletal muscle glut 4 transcription and gene expression (143). It has recently been shown by Devaskar and colleagues (144) that IUGR increases MEF2D (inhibitor) and decreases MEF2A (activator) and MyoD (co-activator) binding to the glut4 promoter in skeletal muscle. Interestingly, no differential methylation of these three and other CpG clusters in the glut4 promoter was found. They found that DNMT1 in postnatal, DNMT3a, and DNMT3b in adult was differentially recruited with increased $\mathrm{MeCP} 2$ (methyl CpG-binding protein) concentrations to bind the IUGR glut4 gene. Covalent modifications of the histone $(\mathrm{H})$ code consisted of $\mathrm{H} 3 \mathrm{~K} 14$ de-acetylation mediated by recruitment of histone deacetylase (HDAC) 1 and enhanced association of HDAC4 enzymes. This set the stage for Suv39H1 methylase-mediated di-methylation of H3 K9 and increased recruitment of heterochromatin protein 1 , which partially inactivates postnatal and adult IUGR glut 4 gene transcription. To date, it has not been demonstrated that these histone modifications are directly responsible for altered glut 4 expression. Nonetheless, these studies show that histone modifications can be propogated.

\section{Conclusions}

The human and animal studies described above clearly show that an adverse intrauterine environment associated with fetal growth retardation or fetal overgrowth results in impaired function and development of the $\beta$-cell, which in turn leads to the development of type 2 diabetes. Animal models demonstrate that the cellular and molecular mechanisms underlying altered B-cell development are related to abnormal mitochondrial function and epigenetic alterations of key $ß$-cell genes.

Much of the recent progress in understanding epigenetic phenomena is directly attributable to technologies that allow researchers to pinpoint the genomic location of proteins that package and regulate access to the DNA. The advent of DNA microarrays and inexpensive DNA sequencing has allowed many of those technologies to be applied to the whole genome. It is possible that epigenetic profiling of $\mathrm{CpG}$ islands in the human genome can be used as a tool to identify genomic loci that are susceptible to DNA methylation or loss of DNA methylation.

The genome-wide mapping of histone modifications by ChIP-chip and DNA methylation has led to important insights regarding the mechanism of transcriptional and epigenetic memory, and how different chromatin states are propagated through the genome (145-149). In the near future it is likely that technologies will be developed that will allow genomewide epigenetics studies, especially applied to the limited numbers of cells that can be isolated to a high degree of purity by techniques such as laser capture microscopy. Epigenetic modifications can then be used as biomarkers for disease.

\section{Acknowledgments}

Grant Support: Dr. Rebecca Simmons is supported by the National Institutes of Health grants \#DK55704 and AG20898 


\section{Abbreviations}

$\begin{array}{ll}\text { IUGR } & \text { intrauterine growth retardation } \\ \text { SGA } & \text { small for gestational age } \\ \text { LP } & \text { low protein } \\ \text { HDAC1 } & \text { histone deacetylase 1 }\end{array}$

\section{References}

1. Hales CN, Barker DJP. Type 2 diabetes mellitus: the thrifty phenotype hypothesis. Diabetologia. 1992; 35:595-601. [PubMed: 1644236]

2. Kermack WO. Death rates in Great Britain and Sweden. Lancet. 1934; 1:698-703.

3. Ravelli GP, Stein ZA, Susser MW. Obesity in young men after famine exposure in utero and early infancy. N Eng J Med. 1976; 295:349-353.

4. Barker DJP. The developmental origins of adult disease. Journ Am College Nutrition. 2004; 23:588S-595S.

5. Valdez R, Athens MA, Thompson GH, et al. Birthweight and adult health outcomes in a biethnic poulation in the USA. Diabetologia. 1994; 37:624-531. [PubMed: 7926349]

6. Jaquet D, Gaboriau A, Czernichow P, et al. Insulin resistance early in adulthood in subjects born with intrauterine growth retardation. J Clin Endocrin Metab. 2000; 85:1401-1406.

7. Egeland GM, Skjaerven R, Irgrens LM. Birth characteristics of women who develop gestational diabetes: population based study. BMJ. 2000; 321:546-547. [PubMed: 10968815]

8. Forsen T, Eriksson J, Tuomilehto J, et al. The fetal and childhood growth of persons who develop type 2 diabetes. Ann Int Med. 2000; 133:176-182. [PubMed: 10906831]

9. Rich-Edwards JW, Colditz GA, Stampfer MJ, et al. Birthweight and the risk for type 2 diabetes mellitus in adult women. Ann Intern Med. 1999; 130:278-284. [PubMed: 10068385]

10. Eriksson J, Forsen T, Tuomilehto J, et al. Fetal and childhood growth and hypertension in adult life. Hypertension. 2000; 36:790-794. [PubMed: 11082144]

11. Bavdekar A, Sachdev HS, Fall CHD, et al. Relation of Serial Changes in Childhood Body-Mass Index to Impaired Glucose Tolerance in Young Adulthood. N Eng J Med. 2004; 350:865-875.

12. Whincup PH, Cook DG, Adshead T, et al. Childhood size is more strongly related than size at birth to glucose and insulin levels in 10-11 year-old children. Diabetologia. 1997; 40:319-326. [PubMed: 9084971]

13. Martin RM, McCarthy A, Smith GD, et al. Infant nutrition and blood pressure in early adulthood: the Barry Caerphilly Growth study. Am J Clin Nutr. 2003; 77:1489-1497. [PubMed: 12791629]

14. Law CM, Shiell AW, Newsome CA, et al. Fetal, infant, and childhood growth and adult blood pressure: a longitudinal study from birth to 22 years of age. Circulation. 2002; 105:1088-92. [PubMed: 11877360]

15. Li C, Johnson MS, Goran MI. Effects of low birth weight on insulin resistance syndrome in Caucasian and African-American children. Diabetes Care. 2001; 24:2035-2042. [PubMed: 11723079]

16. Boney CM, Verma A, Tucker R, et al. Metabolic syndrome in childhood: association with birth weight, maternal obesity, and gestational diabetes mellitus. Pediatrics. 2005; 115:290-296.

17. Clausen JO, Borch-Johnsen K, Pedersen O. Relation between birth weight and the insulin sensitivity index in a population sample of 331 young, healthy Caucasians. Am J Epidemiol. 1997; 146:23-31. [PubMed: 9215220]

18. Flanagan DE, Moore VM, Godsland IF, et al. Fetal growth and the physiological control of glucose tolerance in adults: a minimal model analysis. Am J Physiol Endocrinol Metab. 2000; 278:E700E706. [PubMed: 10751205]

19. Van Assche FA, De Prins F, Aerts L, et al. The endocrine pancreas in small-for dates infants. Br j Obstet Gynaecol. 1977; 84:751-753. [PubMed: 336076] 
20. Beringue F, Blondeau B, Castellotti MC, et al. Endocrine pancreas development in growth-retarded human fetuses. Diabetes. 2005; 51:385-391. [PubMed: 11812745]

21. Econimides DL, Proudler A, Nicolaides KH. Plasma insulin in appropriate and small for gestational age fetuses. Am J Obstet Gynecol. 1989; 160:1091-1094. [PubMed: 2658601]

22. Setia S, Sridhar MG, Bhat V, et al. Insulin sensitivity and insulin secretion at birth in intrauterine growth retarded infants. Pathology. 2006; 38:236-238. [PubMed: 16753745]

23. Bazaes RA, Salazar TE, Pittaluga E. Glucose and lipid metabolism in small for gestational age infants at 48 hours of age. Pediatrics. 2003; 111:804-809. [PubMed: 12671116]

24. Jensen CB, Storgaard H, Dela F, et al. Early differential defects of insulin secretion and action in 19-year-old Caucasian men who had low birth weight. Diabetes. 2002; 51:1271-1280. [PubMed: 11916955]

25. Pettitt DJ, Baird HR, Aleck KA, et al. Excessive obesity in offspring of Pima Indian women with diabetes during pregnancy. N Engl J Med. 1983; 308:242-245. [PubMed: 6848933]

26. Pettitt DJ, Aleck KA, Baird HA, et al. Congenital susceptibility to NIDDM: Role of the intrauterine environment. Diabetes. 1988; 37:622-628. [PubMed: 3360218]

27. Martin AO, Simpson JL, Ober C, et al. Frequency of diabetes mellitus in mothers of probands with gestational diabetes: possible maternal influence on the predisposition to gestational diabetes. Am L Obest Gynecol. 1985; 151:471-475.

28. Silverman B, Metzger BE, Cho NH, et al. Impaired glucose tolerance in adolescent offspring of diabetic mothers: Relationship to fetal hyperinsulinism. Diabetes Care. 1995; 18:611-617. [PubMed: 8585997]

29. Holemans K, Aerts L, Van Assche FA. Lifetime consequences of abnormal fetal pancreatic development. J Physiol. 2003; 547:11-20. [PubMed: 12562919]

30. Plagemann A, Harder T, Kohlhoff R, et al. Glucose tolerance and insulin secretion in children of mothers with pregestational IDDM or gestational diabetes. Diabetologia. 1997; 40:1094-1200. [PubMed: 9300247]

31. Barnett AH, Eff C, Leslie RDG, et al. Diabetes in identical twins. Diabetologia. 1981; 20:87-93. [PubMed: 7193616]

32. Newman B, Selby JV, King MC, et al. Concordance for type 2 diabetes mellitus in male twins. Diabetologia. 1987; 30:763-768. [PubMed: 3428496]

33. Warram JH, Martin BC, Krolewski AS, et al. Slow glucose removal rate and hyperinsulinemia precede the development of type II diabetes in the offspring of diabetic parents. Ann Int Med. 1990; 113:909-915. [PubMed: 2240915]

34. Vaag A, Henricksen JE, Madsbad S, et al. Insulin secretion, insulin action, and hepatic glucose production in identical twins discordant for NIDDM. J Clin Inves. 1995; 95:690-698.

35. Hattersley AT, Tooke JE. The fetal insulin hypothesis: an alternative explanation of the association of low birthweight with diabetes and vascular disease. Lancet. 1999; 353:1789-1792. [PubMed: 10348008]

36. Froguel P, Zouali H, Vionnet N. Familial hyperglycemia due to mutations in glucokinase:definition of a subtype of diabetes mellitus. New Eng J Med. 1993; 328:697-702. [PubMed: 8433729]

37. Hattersley AT, Beards F, Ballantyne E, et al. Mutations in the glucokinase gene of the fetus result in reduced birth weight. Nat Genet. 1998; 19:268-270. [PubMed: 9662401]

38. Grant SF, Thorleifsson G, Reynisdottir I, et al. Variant of transcription factor 7-like 2 (TCF7L2) gene confers risk of type 2 diabetes. Nat Genet. 2006; 38:320-323. [PubMed: 16415884]

39. Damcott CM, Pollin TI, Reinhart LJ, et al. Polymorphisms in the transcription factor 7-like 2 (TCF7L2) gene are associated with type 2 diabetes in the Amish: replication and evidence for a role in both insulin secretion and insulin resistance. Diabetes. 2006; 55:2654-2659. [PubMed: 16936218]

40. Saxena R, Gianniny L, Burtt NP, et al. Common single nucleotide polymorphisms in TCF7L2 are reproducibly associated with type 2 diabetes and reduce the insulin response to glucose in nondiabetic individuals. Diabetes. 2006; 55:2890-2895. [PubMed: 17003358] 
41. Munoz J, Lok KH, Gower BA, et al. Polymorphism in the transcription factor 7-like 2 (TCF7L2) gene is associated with reduced insulin secretion in nondiabetic women. Diabetes. 2006; 55:36303634. [PubMed: 17130514]

42. Freathy RM, Weedon MN, Bennett A, et al. Type 2 diabetes TCF7L2 risk genotypes alter birth weight: a study of 24,053 individuals. Am J Hum Genet. 2007; 80:1150-1161. [PubMed: 17503332]

43. Kubaszek A, Markkanen A, Eriksson JG, et al. The association of the K121Q polymorphism of the plasma cell glycoprotein-1 gene with type 2 diabetes and hypertension depends on size at birth. J Clin Endocrinol Metab. 2004; 89:2044-2047. [PubMed: 15126519]

44. Eriksson JG, Lindi V, Uusitupa M, et al. The effects of the Pro12Ala polymorphism of the peroxisome proliferator-activated receptor-gamma2 gene on insulin sensitivity and insulin metabolism interact with size at birth. Diabetes. 2002; 517:2321-2324. [PubMed: 12086968]

45. Rahier J, Wallon J, Henquin JC. Cell populations in the endocrine pancreas of human neonates and infants. Diabetologia. 1981; 20:540-546. [PubMed: 6116638]

46. Von Dorsche H, Reiher H, Hahn HJ. Phases in the early development of the human islet organ. Anat Anz. 1988; 166:69-76. [PubMed: 3056110]

47. Dahri S, Reusens B, Remacle C, et al. Nutritional influences on pancreatic development and potential links with non-insulin-dependent diabetes. Proc. Nutr. Soc. 1995; 54:345-356. [PubMed: 8524881]

48. Dahri S, Snoeck A, Reusens-Billen B, et al. Islet function in off-spring of mothers on low-protein diet during gestation. Diabetes. 1991; 40:115-120. [PubMed: 1748239]

49. Snoeck A, Remacle C, Reusens B, et al. Effect of a low protein diet during pregnancy on the fetal rat endocrine pancreas. Biol Neonate. 1990; 57:107-118. [PubMed: 2178691]

50. Berney DM, Desai M, Palmer DJ, et al. The effects of maternal protein deprivation on the fetal rat pancreas: major structural changes and their recuperation. J Pathol. 1997; 183:109-115. [PubMed: 9370956]

51. Wilson MR, Hughes SJ. The effect of maternal protein deficiency during pregnancy and lactation on glucose tolerance and pancreatic islet function in adult rat offspring. J Endocrinology. 1997; 154:177-185. [PubMed: 9246952]

52. Bertin E, Gangnerau MN, Bellon G, et al. Development of beta-cell mass in fetuses of rats deprived of protein and/or energy in last trimester of pregnancy. Am. J. Physiol. Regul. Integr. Comp. Physiol. 2002; 283:R623-R630. [PubMed: 12184996]

53. Boujendar S, Reusens B, Merezak S, et al. Taurine supplementation to a low protein diet during foetal and early postnatal life restores a normal proliferation and apoptosis of rat pancreatic islets. Diabetologia. 2002; 45:856-866. [PubMed: 12107730]

54. Petrik J, Reusens B, Arany E, et al. A low protein diet alters the balance of islet cell replication and apoptosis in the fetal and neonatal rat, and is associated with a reduced pancreatic expression of insulin-like growth factor-II. Endocrinology. 1999; 140:4861-4873. [PubMed: 10499546]

55. Reusens, B.; Remacle, C. Effects of maternal nutrition and metabolism on the developing endocrine pancreas. In: Barker, DJP., editor. Fetal origins of cardiovascular and lung disease. Marcel Dekker Inc; New York: 2000. p. 339-358.DJP

56. Arantes VC, Teixeira VPA, Reis MAB, et al. Expression of PDX-1 is reduced in pancreatic islets from pups of rat dams fed a low protein diet during gestation and lactation. J Nutr. 2002; 132:3030-3035. [PubMed: 12368391]

57. Melloul D. Transcription factors in islet development and physiology: role of PDX-1 in beta-cell function. Ann N Y Acad Sci. 2004; 1014:28-37. [PubMed: 15153417]

58. Petry CJ, Dorling MW, Pawlak DB, et al. Diabetes in old male offspring of rat dams fed a reduced protein diet. Int J Exp Diabetes Res. 2001; 2:139-143. [PubMed: 12369717]

59. Ozanne SE, Wang CL, Coleman N, et al. Altered muscle insulin sensitivity in the male offspring of protein-malnourished rats. Amer Journ Physiol. 1996; 271:E1128-E1134.

60. Ozanne SE, Jensen CB, Tingey KJ, et al. Low birthweight is associated with specific changes in muscle insulin-signalling protein expression. Diabetologia. 2005; 48:547-552. [PubMed: 15729577] 
61. Ozanne SE, Olsen GS, Hansen LL, et al. Early growth restriction leads to down regulation of protein kinase $C$ zeta and insulin resistance in skeletal muscle. J Endocrinol. 2003; 177:235-241. [PubMed: 12740011]

62. Fernandez-Twinn DS, Wayman A, Ekizoglou S, et al. Maternal protein restriction leads to hyperinsulinemia and reduced insulin-signaling protein expression in 21-mo-old female rat offspring. Am J Physiol Regul Integr Comp Physiol. 2005; 288:R368-373. [PubMed: 15514105]

63. Garofano A, Czernichow P, Bréant B. In utero undernutrition impairs rat beta-cell development. Diabetologia. 1997; 40:1231-1234. [PubMed: 9349607]

64. Garofano A, Czernichow P, Bréant B. Effect of ageing on beta-cell mass and function in rats malnourished during the perinatal period. Diabetologia. 1999; 42:711-718. [PubMed: 10382591]

65. Shen CN, Seckl JR, Slack JM, et al. Glucocorticoids suppress beta-cell development and induce hepatic metaplasia in embryonic pancreas. Biochem J. 2003; 375(Pt 1):41-50. [PubMed: 14509268]

66. Limesand SW, Jensen J, Hutton JC, et al. Diminished B-cell replication contributes to reduced Bcell mass in fetal sheep with intrauterine growth restriction. Am J Physiol Regul Integr Comp Physiol. 2005; 288:R1297-R1305. [PubMed: 15650129]

67. Limesand SW, Rozance PJ, Zerbe GO, et al. Attenuated insulin release and storage in fetal sheep pancreatic islets with intrauterine growth restriction. Endocrinology. 2006; 147:1488-1497. [PubMed: 16339204]

68. Ogata ES, Bussey M, Finley S. Altered gas exchange, limited glucose, branched chain amino acids, and hypoinsulinism retard fetal growth in the rat. Metabolism. 1986; 35:950-977. [PubMed: 3020345]

69. Simmons RA, Templeton L, Gertz S, et al. Intrauterine Growth Retardation Leads to Type II Diabetes in Adulthood in the Rat. Diabetes. 2001; 50:2279-2286. [PubMed: 11574409]

70. Boloker J, Gertz S, Simmons RA. Offspring of Diabetic Rats Develop Obesity and Type II Diabetes in Adulthood. Diabetes. 2002; 51:1499-1506. [PubMed: 11978648]

71. Simmons RA, Gounis AS, Bangalore SA, et al. Intrauterine growth retardation: Fetal glucose transport is diminished in lung but spared in brain. Pediatr Res. 1991; 31:59-63. [PubMed: 1594332]

72. Unterman T, Lascon R, Gotway M, et al. Circulating levels of insulin-like growth factor binding protein-1 (IGFBP-1) and hepatic mRNA are increased in the small for gestational age fetal rat. Endocrinology. 1990; 127:2035-2037. [PubMed: 1698152]

73. Stoffers DA, Desai BM, DeLeon DD, et al. Neonatal exendin-4 prevents the development of diabetes in the intrauterine growth retarded rat. Diabetes. 2003; 52:734-740. [PubMed: 12606515]

74. Myatt L, Eis ALW, Brockman DE, et al. Differential localization of superoxide dismutase isoforms in placental villous tissue of normotensive, pre-eclamptic, and intrauterine growth-restricted pregnancies. J Histochem Cytochem. 1997; 45:1433-1438. [PubMed: 9313805]

75. Karowicz-Billinska A, Suzin J, Sieroszewski. Evaluation of oxidative stress indices during treatment in pregnant women with intrauterine growth retardation. Med Sci Monit. 2002:CR211216. [PubMed: 11889459]

76. Ejima K, Nanri H, Toki N, et al. Localization of thioredoxin reductase and thioredoxin in normal human placenta and their protective effect against oxidative stress. Placenta. 1999; 20:95-101. [PubMed: 9950150]

77. Kato H, Yoneyama Y, Araki T. Fetal plasma lipid peroxide levels in pregnancies complicated by preeclampsia. Gynecol Obstet Invest. 1997; 43:158-61. [PubMed: 9127127]

78. Bowen RS, Moodley J, Dutton MF, et al. Oxidative stress in pre-eclampsia. Acta Obstet Gynecol Scand. 2001; 80:719-25. [PubMed: 11531614]

79. Wang Y, Walsh SW. Increased superoxide generation is associated with decreased superoxide dismutase activity and mRNA expression in placental trophoblast cells in pre-eclampsia. Placenta. 2001; 22:206-212. [PubMed: 11170825]

80. Wang Y, Walsh SW. Placental mitochondria as a source of oxidative stress in pre-eclampsia. Placenta. 1998; 19:581-586. [PubMed: 9859861]

81. Panten U, Zielman S, Langer J, et al. Regulation of insulin secretion by energy metabolism in pancreatic B-cell mitochondria. Biochem J. 1984; 219:189-196. [PubMed: 6372787] 
82. Newgard CB, McGarry JD. Metabolic coupling factors in pancreatic $\beta$-cell signal transduction. Annu Rev Biochem. 1995; 64:689-719. [PubMed: 7574498]

83. Schuit F. Metabolic fate of glucose in purified islet cells. Glucose regulated anaplerosis in B-cells. J Biol Chem. 1997; 272:18572-18579. [PubMed: 9228023]

84. Mertz RJ, Worley JF III, Spencer B, et al. Activation of stimulus-secretion coupling in pancreatic B-cells by specific products of glucose metabolism. J Biol Chem. 1996; 271:4838-3845. [PubMed: 8617753]

85. Ortsater H, Liss P, Akerman KEO. Contribution of glycolytic and mitochondrial pathways in glucose-induced changes in islet respiration and insulin secretion. Pflugers Arch Eur J Physiol. 2002; 444:506-512. [PubMed: 12136270]

86. Antinozzi PA, Ishihara H, Newgard CB, et al. Mitochondrial metabolism sets the maximal limit of fuel-stimulated insulin secretion in a model pancreatic beta cell. A survey of four fuel secretagogues. J Biol Chem. 2002; 277:11746-11755.

87. Malaisse WJ, Hutton JC, Carpinelli AR, et al. The stimulus-secretion coupling of amino acidinduced insulin release. Metabolism and cationic effects of leucine. Diabetes. 1980; 29:431-437.

88. Lenzen S, Schmidt W, Rustenbeck I, et al. 2-Ketoglutarate generation in pancreatic B-cell mitochondria regulates insulin secretory action of amino acids and 2-keto acids. Biosci Rep. 1986; 6:163-169. [PubMed: 3521757]

89. Noda M, Yamashita S, Takahashi N, et al. Switch to anaerobic glucose metabolism with NADH accumulation in the beta-cell model of mitochondrial diabetes. Characteristics of beta HC9 cells deficient in mitochondrial DNA transcription. J Biol Chem. 2002; 277:41817-41826. [PubMed: 12169697]

90. Lenzen S, Drinkgern J, Tiedge M. Low antioxidant enzyme gene expression in pancreatic islets compared with various other mouse tissues. Free Radic Biol Med. 1996; 20:463-466. [PubMed: 8720919]

91. Tiedge M, Lortz S, Drinkgern J, et al. Relationship between antioxidant enzyme gene expression and antioxidant defense status of insulin-producing cells. Diabetes. 1997; 46:1733-1742. [PubMed: 9356019]

92. Maechler P, Jornot L, Wollheim CB. Hydrogen peroxide alters mitochondrial activation and insulin secretion in pancreatic beta cells. J Biol Chem. 1999; 274:27905-27913. [PubMed: 10488138]

93. Sakai K, Matsumoto K, Nishikawa T, et al. Mitochondrial reactive oxygen species reduce insulin secretion by pancreatic ß-cells. Biochem Biophys Res Comm. 2003; 300:216-222. [PubMed: 12480546]

94. Kaneto H, Xu G, Fujii N, et al. Involvement of c-Jun N-terminal kinase in oxidative stressmediated suppression of insulin gene expression. J Biol Chem. 2002; 277:30010-30018. [PubMed: 12011047]

95. Kaneto HH, Xu G, Fujii N, et al. Involvement of protein kinase C beta 2 in c-myc induction by high glucose in pancreatic beta-cells. J Biol Chem. 2002; 277:3680-3685. [PubMed: 11714718]

96. Kaneto H, Xu G, Song KH, et al. Activation of the hexosamine pathway leads to deterioration of pancreatic beta-cell function through the induction of oxidative stress. J Biol Chem. 2001; 276:31099-31104. [PubMed: 11390407]

97. Kaneto H, Kajimoto Y, Fujitani Y, et al. Oxidative stress induces p21 expression in pancreatic islet cells: possible implication in beta-cell dysfunction. Diabetologia. 1999; 42:1093-1097. [PubMed: 10447521]

98. Jonas JC, Laybutt DR, Steil GM, et al. High glucose stimulates early response gene c-Myc expression in rat pancreatic beta cells. J Biol Chem. 2001; 276:35375-35381. [PubMed: 11457846]

99. Jonas JC, Sharma A, Hasenkamp W, et al. Chronic hyperglycemia triggers loss of pancreatic beta cell differentiation in an animal model of diabetes. J Biol Chem. 1999; 274:14112-14121. [PubMed: 10318828]

100. Efanova IB, Zaitsev SV, Zhivotovsky B, et al. Glucose and tolbutamide induce apopotosis in pancreatic B-cells. J Biol Chem. 1998; 273:22501-22507. 
101. Moran A, Zhang HJ, Olsonm LK, et al. Differentiation of glucose toxicity from ß-cell exhaustion during the evolution of defective insulin gene expression in the pancreatic islet cell line, HITT15. J Clin Invest. 2000; 99:534-539. [PubMed: 9022089]

102. Donath MY, Gross DJ, Cerasi E, et al. Hyperglycemia-induced ß-cell apoptosis in pancreatic islets of Psammomys obesus during development of diabetes. Diabetes. 1999; 48:738-744. [PubMed: 10102689]

103. Silva JP, Kohler M, Graff C, et al. Impaired insulin secretion and B-cell loss in tissue specific knockout mice with mitochondrial diabetes. Nature Genetics. 2000; 26:336-340. [PubMed: 11062475]

104. Simmons RA, Suponitsky-Kroyter I, Selak M. Progressive accumulation of mitochondrial DNA mutations and decline in mitochondrial function lead to beta-cell failure. J Biol Chem. 2005; 280:28785-28791. [PubMed: 15946949]

105. Bannister AJ, Kouzarides T. Reversing histone methylation. Nature. 2005; 436:1103-1106. [PubMed: 16121170]

106. Bernstein E, Allis CD. RNA meets chromatin. Genes Dev. 2005; 19:1635-1655. [PubMed: 16024654]

107. Sproul D, Gilbert N, Bickmore WA. The role of chromatin structure in regulating the expression of clustered genes. Nat Rev Genet. 2005; 6:775-781. [PubMed: 16160692]

108. Schubeler D, Lorincz MC, Cimbora DM, et al. Genomic targeting of methylated DNA: influence of methylation on transcription, replication, chromatin structure, and histone acetylation. Mol Cell Biol. 2000; 20:9103-1912. [PubMed: 11094062]

109. Galm O, Yoshikawa H, Esteller M, et al. SOCS-1, a negative regulator of cytokine signaling, is frequently silenced by methylation in multiple myeloma. Blood. 2003; 101:2784-2788. [PubMed: 12456503]

110. Yoshikawa H, Matsubara K, Qian GS, et al. SOCS-1, a negative regulator of the JAK/STAT pathway, is silenced by methylation in human hepatocellular carcinoma and shows growthsuppression activity. Nat Genet. 2001; 28:29-35. [PubMed: 11326271]

111. He B, You L, Uematsu K, et al. SOCS-3 is frequently silenced by hypermethylation and suppresses cell growth in human lung cancer. Proc Natl Acad Sci U S A. 2003; 100:1413314138. [PubMed: 14617776]

112. Shiraishi M, Sekiguchi A, Oates AJ, et al. HOX gene clusters are hotspots of de novo methylation in CpG islands of human lung adenocarcinomas. Oncogene. 2002; 21:3659-3663. [PubMed: 12032868]

113. So K, Tamura G, Honda T, et al. Multiple tumor suppressor genes are increasingly methylated with age in non-neoplastic gastric epithelia. Cancer Sci. 2006; 97:1155-1158. [PubMed: 16952303]

114. Takahashi T, Shigematsu H, Shivapurkar N, et al. Aberrant promoter methylation of multiple genes during multistep pathogenesis of colorectal cancers. Int J Cancer. 2006; 118:924-931. [PubMed: 16108009]

115. Feltus FA, Lee EK, Costello JF, et al. Predicting aberrant CpG island methylation. Proc Natl Acad Sci U S A. 2003; 100:12253-12258. [PubMed: 14519846]

116. Cerda S, Weitzman SA. Influence of oxygen radical injury on DNA methylation. Mutat Res. 1997; 386:141-152. [PubMed: 9113115]

117. Drake J, Petroze R, Castegna A, et al. 4-Hydroxynonenal oxidatively modifies histones: implications for Alzheimer's disease. Neurosci Lett. 2004; 356:155-158. [PubMed: 15036618]

118. Gilmour PS, Rahman I, Donaldson K, et al. Histone acetylation regulates epithelial IL-8 release mediated by oxidative stress from environmental particles. Am J Physiol Lung Cell Mol Physiol. 2003; 284:L533-540. [PubMed: 12573991]

119. Rahman I, Gilmour PS, Jimenez LA, et al. Oxidative stress and TNF-alpha induce histone acetylation and NF-kappaB/AP-1 activation in alveolar epithelial cells: potential mechanism in gene transcription in lung inflammation. Mol Cell Biochem. 2002; 234-235:239-248. [PubMed: 12162440] 
120. MacLennan NK, James SJ, Melnyk S, et al. Uteroplacental insufficiency alters DNA methylation, one-carbon metabolism, and histone acetylation in IUGR rats. Physiol Genomics. 2004; 18:4350. [PubMed: 15084713]

121. Pham TD, MacLennan NK, Chiu CT, et al. Uteroplacental insufficiency increases apoptosis and alters p53 gene methylation in the full-term IUGR rat kidney. Am J Physiol Regul Integr Comp Physiol. 2003; 285:R962-R970. [PubMed: 12869365]

122. Fu Q, McKnight RA, Yu X, et al. Uteroplacental insufficiency induces site-specific changes in histone $\mathrm{H} 3$ covalent modifications and affects DNA-histone H3 positioning in day 0 IUGR rat liver. Physiological Genomics. 2004; 20:108-116. [PubMed: 15494474]

123. Ke X, Lei Q, James SJ, et al. Uteroplacental insufficiency affects epigenetic determinants of chromatin structure in brains of neonatal and juvenile IUGR rats. Physiol Genomics. 2006; 25:16-28. [PubMed: 16380407]

124. Fu Q, McKnight RA, Yu X, Callaway CW, et al. Growth retardation alters the epigenetic characteristics of hepatic dual specificity phosphatase 5. FASEB J. 2006; 20:2127-2129. [PubMed: 16940436]

125. Park JH, Stoffers DA, Nicholls RD, et al. Development of type 2 diabetes following intrauterine growth retardation in rats is associated with progressive epigenetic silencing of Pdx1. J Clin Invest. 2008; 118:2316-2324. [PubMed: 18464933]

126. Qian J, Kaytor EN, Towle HC, et al. Upstream stimulatory factor regulates Pdx-1 gene expression in differentiated pancreatic B-cells. Biochem J. 1999; 341:315-322. [PubMed: 10393088]

127. Sharma S, Leonard J, Lee S, et al. Pancreatic islet expression of the homeobox factor STF-1 (Pdx-1) relies on an E-box motif that binds USF. J Biol Chem. 1996; 271:2294-2299. [PubMed: 8567692]

128. Franco R, Schoneveld O, Georgakilas AG, et al. Oxidative stress, DNA methylation and carcinogenesis. Cancer Lett. 2008; 266:6-11. [PubMed: 18372104]

129. Yauk C, Polyzos A, Rowan-Carroll A, et al. Germ-line mutations, DNA damage, and global hypermethylation in mice exposed to particulate air pollution in an urban/industrial location. Pro. Natl Acad Sci USA. 2008; 105:605-610.

130. Hitchler MJ, Domann FE. An epigenetic perspective on the free radical theory of development. Free Radic Biol Med. 2007; 43:1023-1036. [PubMed: 17761298]

131. Ihara Y, Toyokuni S, Uchida K, et al. Hyperglycemia causes oxidative stress in pancreatic betacells of GK rats, a model of type 2 diabetes. Diabetes. 1999; 48:927-932. [PubMed: 10102716]

132. Silva JP, Köhler M, Graff C, et al. Impaired insulin secretion and B-cell loss in tissue specific knockout mice with mitochondrial diabetes. Nat Genet. 2000; 26:336-340. [PubMed: 11062475]

133. Kaneto H, Xu G, Song KH, et al. Activation of the hexosamine pathway leads to deterioration of pancreatic beta-cell function through the induction of oxidative stress. J Biol Chem. 2001; 276:31099-31104. [PubMed: 11390407]

134. Sakuraba H, Mizukami H, Yagihashi N, et al. Reduced beta-cell mass and expression of oxidative stress-related DNA damage in the islet of Japanese Type II diabetic patients. Diabetologia. 2002; 45:85-96. [PubMed: 11845227]

135. Sakai K, Matsumoto K, Nishikawa T, et al. Mitochondrial reactive oxygen species reduce insulin secretion by pancreatic $\beta$-cells. Biochem Biophys Res Comm. 2003; 300:216-222. [PubMed: 12480546]

136. Bachman KE, Park BH, Rhee I, et al. Histone modifications and silencing prior to DNA methylation of a tumor suppressor gene. Cancer Cell. 2003; 3:89-95. [PubMed: 12559178]

137. Kouzarides T. Histone methylation in transcriptional control. Curr Opin Genet Dev. 2002; 12:198-209. [PubMed: 11893494]

138. Bernardo AS, Hay CW, Docherty K. Pancreatic transcription factors and their role in the birth, life and survival of the pancreatic beta cell. Mol Cell Endocrinol. 2008; 294:1-9. [PubMed: 18687378]

139. Thamotharan M, Shin BC, Suddirikku DT, et al. GLUT4 expression and subcellular localization in the intrauterine growth-restricted adult rat female offspring. Am J Physiol. 2005; 288:E935E947. 
140. Ozanne SE, Jensen CB, Tingey KJ, et al. Low birthweight is associated with specific changes in muscle insulin-signaling protein expression. Diabetologia. 2005; 48:547-552. [PubMed: 15729577]

141. Fueger PT, Shearer J, Bracy DP, et al. Control of muscle glucose uptake: test of the rate-limiting step paradigm in conscious, unrestrained mice. J Physiol. 2005; 562:925-935. [PubMed: 15576451]

142. Karnieli E, Armoni M. Transcriptional regulation of the insulin-responsive glucose transporter GLUT4 gene: from physiology to pathology. Am J Physiol Endocrinol Metab. 2008; 295:E3845. [PubMed: 18492767]

143. Moreno H, Serrano AL, Santalucía T, et al. Differential regulation of the muscle-specific GLUT4 enhancer in regenerating and adult skeletal muscle. J Biol Chem. 2003; 278:40557-40564. [PubMed: 12893821]

144. Raychaudhuri N, Raychaudhuri S, Thamotharan M, et al. Histone code modifications repress glucose transporter 4 expression in the intrauterine growth-restricted offspring. J Biol Chem. 2008; 283:13611-13626. [PubMed: 18326493]

145. Gebhard C, Schwarzfischer L, Pham TH, et al. Genome-wide profiling of CpG methylation identifies novel targets of aberrant hypermethylation in myeloid leukemia. Cancer Res. 2006; 66:6118-6128. [PubMed: 16778185]

146. Korshunova Y, Maloney RK, Lakey N, et al. Massively parallel bisulphite pyrosequencing reveals the molecular complexity of breast cancer-associated cytosine-methylation patterns obtained from tissue and serum DNA. Genome Res. 2008; 18:19-29. [PubMed: 18032725]

147. Mori Y, Cai K, Cheng Y, et al. A genome-wide search identifies epigenetic silencing of somatostatin, tachykinin-1, and 5 other genes in colon cancer. Gastroenterology. 2006; 131:797808. [PubMed: 16952549]

148. Lieb JD, Beck S, Bulyk ML, et al. Applying whole-genome studies of epigenetic regulation to study human disease. Cytogenet. Genome Res. 2006; 114:1-15. [PubMed: 16717444]

149. Kim TH, Barrera LO, Zheng M, et al. A high-resolution map of active promoters in the human genome. Nature. 2005; 436:876-880. [PubMed: 15988478] 


\section{Control islets}
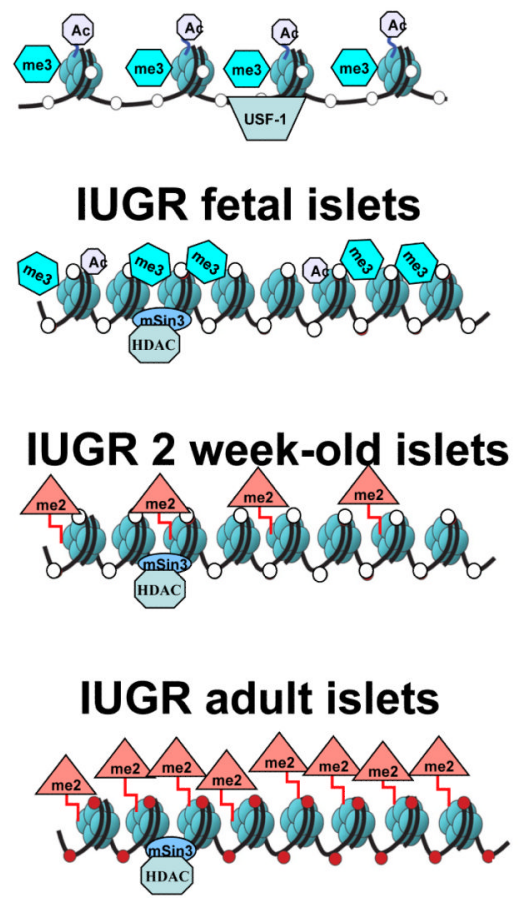

Figure 1. Summary of epigenetic changes at $P d x I$ in IUGR rats during the development of type 2 diabetes

In pancreatic $B$-cells (top), the $P d x 1$ proximal promoter is normally found in an unmethylated (white circles) open chromatin state allowing access to transcription factors such as USF-1 and associated with nucleosomes characterized by acetylated (Ac, blue octagons) histones $\mathrm{H} 3$ and $\mathrm{H} 4$ and with trimethylated $\mathrm{H} 3 \mathrm{~K} 4$ (Me, green hexagons). In IUGR fetal and 2 week islets (middle) histone acetylation is progressively lost through association with a mSin3A-HDAC1-DNMT1 repressor complex, with trimethylated H3K4 disappearing and dimethylated H3K9 (Me, red hexagons) appearing after birth. IUGR adult islets are characterized by inactive chromatin with dimethylated H3K9 and extensive DNA methylation (red circles) locking in the transcriptionally silent state of $P d x 1$. 